УДК 339.923

DOI: $10.14451 / 1.177 .136$

\title{
США - КИТАЙ: СПАД ВЗАИМНОЙ ТОРГОВЛИ
}

(c) 2019 Гусарова Светлана Анатольевна

доктор экономических наук, доцент, ведущий научный сотрудник, Кафедра мировой экономики Российский экономический университет имени Г.В. Плеханова, Россия, Москва

E-mail: s-gusarova@mail.ru

Проанализированы проблемы торговли США с Китаем. Эскалация торгово-экономических отношений между ними приводит к замедлению темпов роста всей мировой экономики. Китай вынужден искать новых торговых партнеров, в том числе в группе БРИКС. С помощью регрессионного анализа доказано, что потенциал торгового сотрудничества Китая со странами БРИКС является более высоким, чем его взаимодействие с США.

Ключевые слова: Китай, США, торговое сотрудничество, «торговая война», страны БРИКС, экономический потенциал.

\section{Введение}

На протяжении многих лет между Китаем и США велось торговое сотрудничество, приносящее пользу не только этим двум странам, но и всему миру. При взаимодействии с основными торговыми партнерами (в том числе с Китаем), США проводят политику введения дополнительных тарифов. В результате инициированных США обвинений Китая в нарушении прав интеллектуальной собственности, в проведении нечестной торговой политики, приводящей к дефициту торговых двусторонних отношений, американская сторона с марта 2018 года ввела дополнительные тарифы и инвестиционные ограничения. При этом, лауреат Нобелевской премии американский экономист Пол Кругман отметил, что «непонятно, что Трамп хочет от Китая...» [3, С.11]. Стремясь урегулировать спорные вопросы путем переговоров, страны провели несколько раундов экономических и торговых консультаций для стабилизации двусторонних торговых отношений. Однако договоренности по принципиальным вопросам не были достигнуты. Начавшаяся «торговая война» между Китаем и США оказывает влияние на развитие экономик не только этих стран, но и всего мира.

\section{1. Развитие торговли между Китаем и} США

В 2018 году на долю КНР приходилось 12,8\% мирового экспорта и 10,8\% мирового импорта товаров. За 2001-2018 годы объем товарного экспорта Китая увеличился в 9,3 раз до 2487,1 млрд. долл., а товарного импорта - в 8,8 раз до 2135,9 млрд. долл. Положительное сальдо торгового баланса Китая увеличилось за 2001-2018 годы в 15,6 раз. Разница между экспортом и импортом товаров составила в 2018 году 2,6\% ВВП Китая. Экспортная квота Китая (отношение объема экспорта товаров к ВВП), являющаяся показателем открытости экономики, за 2001-2018 годы постепенно снижалась (с 19,9\% до 18,3\%) [6], что свидетельствует о том, что в стране произошла смена курса с экспортной ориентации на расширение внутреннего потребления. Данная политика позволяет обеспечить уменьшение зависимости экономики Китая от иностранного потребления, избежать уязвимости от внешней конъюнктуры.

В свою очередь, на долю США приходилось 8,6\% мирового товарного экспорта (1665,3 млрд. долл.) и 13,2\% мирового товарного импорта (2611,4 млрд. долл.) [6].

В 2018 году объем китайского экспорта товаров в США увеличился против 2001 года в 8,8 раз и составлял 476,6 млрд. долл. Доля экспорта в США в общем объеме китайского экспорта товаров в 2018 году равнялась 19,2\%. Основной объем экспорта Китая в США составили следующие виды товаров: текстиль и одежда на сумму 53,3 млрд. долл., обувь - 13,7 млрд. долл., продукция химической промышленности - 19,2 млрд. долл., продовольственные товары $-8,2$ млрд. долл., металлические руды и металлы 2,8 млрд. долл., железо и сталь - 2,7 млрд. долл., сельскохозяйственное сырье - 1,5 млрд. долл. Вместе с тем, в 2018 году Китай экспортировал в США не только трудо- и ресурсоемкие товары, но и высокотехнологичную продукцию на сумму 171 млрд. долл., в том числе электронику, запасные части и компоненты - 137,7 млрд. долл. [6]. 
За 2001-2018 годы объем импорта Китаем американских товаров вырос в 6,4 раза до 167,9 млрд. долл. Китай является ключевым импортером ряда американских товаров (самолетов, сои, автомобилей, интегральных микросхем и хлопка). Китай импортировал из США также следующие виды товаров: высокотехнологичную продукцию на 68,9 млрд. долл. (в том числе электронику, запасные части и компоненты - 20,7 млрд. долл.), химические товары 22,3 млрд. долл., продукты питания - 24,3 млрд. долл. (в том числе масличные культуры -14 млрд. долл., рыбу и морепродукты $-1,3$ млрд. долл., овощи и фрукты - 1,1 млрд. долл.), сельскохозяйственное сырье -10 млрд. долл., макулатуру - 4,3 млрд. долл., металлолом - 5,4 млрд. долл., газ, нефть и нефтепродукты - 5,3 млрд. долл., древесные материалы -3 млрд. долл., и др. [6].

Сальдо торгового баланса КНР с США было положительным, увеличилось за этот период в 10,9 раз и составило в 2018 году 308,7 млрд. долл. [6]. Для преодоления трудностей Китай заинтересован в росте экспорта продукции и обеспечении профицита торгового баланса.

Китайская и американская экономики взаимосвязаны, Китай и США являются крупнейшими торговыми партнерами друг для друга и важным источником инвестиций. Безусловно, США являются одним из основных рынков сбыта китайских товаров. Но китайская экономика не зависит полностью от торговли с США. Как было указано выше, объем китайского экспорта в США составляет лишь пятую часть его экспорта в мировую экономику.

2. Инвестиционное сотрудничество между Китаем и США

За 1990-2018 годы китайские прямые иностранные инвестиции (ПИИ) в США достигли 145,14 млрд. долл., а американские ПИИ в Китай - 269,43 млрд. долл. [5]. Наибольшие инвестиции США в Китай были осуществлены за 1990-2018 годы в сектор информационнокоммуникационных технологий (ИКТ) $(43,71$ млрд. долл., или 16,2\% всех американских ПИИ в китайскую экономику), в производство химической продукции и металлов (31,33 млрд. долл., или $11,6 \%)$ в производство автомобилей и транспортного оборудования (25,66 млрд. долл., или 9,5\%), в энергетический комплекс $(22,48$ млрд. долл., или 8,3\%), в недвижимость (22,23 млрд. долл., или 8,3\%), в сельское хозяйство и продовольственный комплекс (20,66 млрд. долл., или $7,7 \%)$, в производство машинного оборудования (19,71 млрд. долл., или 7,3\%), в фармацевтику, в биотехнологии $(16,64$ млрд. долл., или $6,2 \%)$ [5].

Первоначально американские инвесторы вкладывали средства в сборку ИТ-оборудования, используя преимущества Китая в дешевой рабочей силе (Motorola, Lucent, Seagate). С ростом квалификации китайской рабочей силы произошло увеличение инвестиций в крупные предприятия, производящие полупроводники (завод Freescale в Тяньцзине - 600 млн. долл., Micron в Шэньси - 550 млн. долл., Intel в Даляне $-2,5$ млрд. долл.) [5].

С 2014 года наблюдался резкий рост инвестиций американских компаний (Intel, Qualcomm, Alpha \& Omega, Fairchild) в китайские предприятия, занимающиеся цифровыми услугами. В 2017 году увеличились инвестиции (Apple, Google) в исследования и разработки в области ИКТ. Компания «Эппл» (Apple) строит новые центры обработки данных в Гуйчжоу, куда переносит операции по хранению данных. Однако в 2018 году произошло заметное сокращение американских инвестиций в ИКТ, что было связано с началом «торговой войны» с Китаем.

Одним из основных направлений китайских инвестиций в США являются ПИИ в ИКТ. За 19902018 годы объем сделок в этот сектор экономики составил 17,13 млрд. долл. (или 11,8\% китайских инвестиций в американскую экономику) [5]. Основная доля внедрения китайских инвестиций в ИКТ США осуществлялась компаниями (Huawei, ZTE, Lenovo), занимающимися созданием информационно-коммуникационного оборудования, разработкой программного обеспечения.

В 2018 году общий объем инвестиций в исследования и разработки в Китае достиг 474,81 млрд. долл., занимая второе место в мире [7]. Количество заявок на патенты достигло 1,442 млн. [4]. В 2018 году китайская компания «Хуавей» (Huawei Technologies) была первой в мире по числу поданных заявок на изобретения среди ТОП-50 компаний - 5405 заявок [2, С. 35]. Наибольшая доля выданных патентов на изобретения в Китае была в следующих сферах: цифровая связь, компьютерные технологии, электрические аппараты и оборудование, измерительные приборы, фармацевтика. Администрация американского президента «похоже обеспокоена продвижением в Китае индустрии высоких 
технологий, которая в действительности может угрожать доминированию США» [3, С. 11].

3. Обострение торговых взаимодействий между КНР и США

В начале 2018 года США объявили китайскую торговую политику несправедливой, что привело к началу «торговой войны» между двумя державами. США, намериваясь устранить огромный дисбаланс в торговле с Китаем, обвинили ее в краже объектов американской интеллектуальной собственности, поставили перед собой цель препятствовать Китаю в завоевании лидерства в глобальном технологическом секторе. Было инициировано расследование, в результате которого сделан вывод, что Китай, используя дискриминационные практики, наносит вред американской торговле. США обвинили Китай в несправедливом управлении курсом национальной валюты для помощи экспортерам товаров.

Между США и Китаем было проведено двенадцать раундов переговоров, которые не привели к положительным результатам. В мае 2019 года США ввели пошлины в размере 10-25\% на импорт китайских товаров на сумму 200 млрд. долл. В июне 2019 года Китай ответил увеличением тарифов (от 5\% до 25\%) на импортируемые американские товары объемом 60 млрд. долл.

Очередная эскалация торговых отношений между Китаем и США произошла после заявления США о намерении ввести 10\% пошлины на китайский импорт в 300 млрд. долл. В ответ Китай приостановил ввоз в страну американских сельскохозяйственных товаров. Народный банк Китая установил в начале августа 2019 года средний обменный курс юаня ниже психологической отметки в 7 юаней за доллар США. Таким образом, по мнению Пола Кругмана, Китай «пытается учить Трампа экономике» [3, С. 1].

В конце мая 2019 года Министерство торговли США ввело санкции против крупнейшей китайской телекоммуникационной компании, использующей в работе американские компоненты, технологии и программное обеспечение (Huawei Technologies Co. Ltd.). Причины этого peшения были не столько экономические, сколько политические: Китай не поддержал американские санкции против Ирана (компания Huawei была обвинена в продаже американских технологий Ирану и Северной Корее). Китай намерен осуществить курс на технологическую самостоятельность, снизить зависимость от США, актив- но развивать собственную научно-техническую базу. Компания «Хуавей» (Huawei) предполагает в будущем работать без американских комплектующих (чипов) и заменить их своей собственной операционной системой и оборудованием. Место американских поставщиков полупроводников и чипов в Китай готовы заменить не только китайские компании, но и европейские производители.

Многие американские компании выступают против введения пошлин на китайские товары, которые приводят к увеличению издержек американских компаний. Проводимые реформы в стране, направленные на улучшение инвестиционного климата, повлияли на решение некоторых западных компаний разместить в Китае предприятия с высокой добавленной стоимостью. Например, в 2017 году компания Боинг (Boeing) приступила к созданию сборочного производства в Китае - первому подобному проекту за пределами США.

Растущая напряженность в отношениях между двумя крупнейшими экономиками мира продолжает создавать неопределенность, нарушать глобальные цепочки поставок, что может сказаться на замедлении роста глобальной экономики. По прогнозу Всемирного банка, рост мировой экономики в результате постоянных торговых трений (одного из основных понижающих факторов) в 2019 году будет снижен до $2,6 \%$, в 2020 году - до 2,7\%, в 2021 году - до 2,8\% (против 3\% в 2018 году) [1, С. 4].

4. Переориентация Китая на торговое сотрудничество с другими странами

«Торговая война» между Китаем и США приводит к тому, что Китай вынужден проводить корректировку логистических цепочек и переориентацию на поставки товаров из других стран. Такими партнерами для Китая могут быть многие государства, в том числе страны БРИКС, которые осуществляют сотрудничество на основе взаимовыгодности и взаимодополняемости.

На фоне начавшейся «торговой войны» С США, Китай наращивает торгово-инвестиционное сотрудничество со странами БРИКС. Россия и Бразилия, пытаясь занять место американских поставщиков сельскохозяйственной продукции, увеличивают свои поставки соевых бобов и других сельскохозяйственных товаров в Китай.

Для определения эффекта торгового сотрудничества Китая с США и со странами БРИКС были рассчитаны уравнения регрессии: 
- Торговое сотрудничество с США:

$Y=22,5155 \mathrm{X}_{1}-1857,2805$

- Торговое сотрудничество со странами БРИКС:

$Y=30,6661 \mathrm{X}_{1}+400,9077$

Результаты регрессионного анализа свидетельствует о более высоком потенциале дальнейшего внешнеторгового сотрудничества между Китаем и странами группы БРИКС, чем Китая с США. Рассчитанное уравнение регрессии позволило установить, что увеличение внешнеторгового оборота Китая с другими странами БРИКС на 1 долл. приводит в среднем к повышению его ВВП на 30,7 долл., а увеличение его внешнеторгового оборота с США на 1 долл. приводит в среднем к повышению объема ВВП Китая на 22,5 долл.

\section{Выводы}

В «торговой войне» двух крупнейших экономик мира не может быть победителей. Пострадают не только США и Китай, но и другие страны мира. В результате торговых проблем прогнозируется снижение объемов мирового ВВП. Ввод таможенных пошлин и ограничений США в отношении китайских товаров, снижение товарооборота между двумя крупнейшими державами приводит к поиску Китаем новых, более предсказуемых партнеров. У многих стран мира (в том числе стран БРИКС) появилась возможность занять места американских поставщиков разных товаров. Потенциал дальнейшего развития торгового сотрудничества Китая со странами БРИКС является высоким.

\section{Библиографический список}

1. Global Economic prospects: Heightened Tensions, Subdued Investment// World Bank Group. - June 2019. - 161 p.

2. Patent Cooperation Treaty Yearly Review 2019: The International Patent System // World Intellectual Property Organization.-Geneve, 2019.- P. 161.

3. Paul Krugman. China tutors Trump on economics // The New York Times. - 2019.- August 10-11.- P. 1, 11 .

4. Statistical Country Profile [Электронный ресурс]// World Intellectual Property Organization Industrial Research Institute.- Режим доступа: http://www.wipo.int/ipstats/en/statistics/country_profile/profile.jsp?code=ZA (дата обращения: 22.07.2019).

5. The US-China Investment Hub [Электронный ресурс].- Режим доступа: https://www.us-china-fdi.com/uschina-foreign-direct-investments/data (дата обращения: 22.06.2019).

6. UNCTADSTAT [Электронный ресурс].- Режим доступа: http://unctadstat.unctad.org/wds/TableViewer/ tableView.aspx (дата обращения: 06.08.2019).

7. 2018 Global R\&D Funding Forecast [Электронный ресурс] // Industrial Research Institute.- Режим доступа: http://digital.rdmag.com/researchanddevelopment/2018_global_r_d_funding_forecast?pg=5\#pg5 (дата обращения 23.05.2019). 